\title{
Immunological specificity of oral Eubacterium species
}

\author{
Futoshi NAKazawa and Etsuro Hoshino*
}

Department of Oral Microbiology, School of Dentistry, Niigata University, Gakko-cho-dori 2, Niigata 951, Japan

(Received 13 April 1993; revised 2 June 1993; accepted 18 June 1993)

\begin{abstract}
Antigens of Eubacterium species including E. alactolyticum, E. brachy, E. nodatum, E. saburreum, E. timidum, $E$. yurii subsp. yurii and $E$. yurii subsp. margaretiae, which have been isolated frequently from periodontal pockets and associated with periodontal diseases, were extracted by ultrasonication from whole bacterial cells. Antigens were also prepared from $E$. aerofaciens, $E$. lentum and $E$. rectale, which have been found in intestinal tracts and infected abscesses in human oral cavities. The antigens of the oral Eubacterium species were compared with antigens from $E$. limosum, the type species of the genus Eubacterium, by using SDS-PAGE and Western immunoblot assays. SDS-PAGE gels stained with Coomassie brilliant blue indicated that no major peptide bands were common among the Eubacterium species examined. The protein profile patterns were distinctly different from each other. Western immunoblotting reactions with rabbit antisera showed that the Eubacterium species could be clearly distinguished serologically, and that the species-specific antigens were peptide components of ultrasonic extracts from the whole bacterial cells. The present study demonstrates that these Eubacterium species show great heterogeneity in their peptide components and immunological reactions, which may be useful for identification of the Eubacterium species from human oral specimens.
\end{abstract}

\section{Introduction}

Micro-organisms belonging to the genus Eubacterium (non-sporing, Gram-positive, obligately anaerobic rods) have been isolated from human oral specimens including those taken from periodontal pockets (Moore et al., 1982a, 1985; Uematsu \& Hoshino, 1992), dental pulps (Hoshino et al., 1992a) and carious dentines (Ando et al., 1990; Edwardsson, 1974; Hoshino, 1985). Within the past decade, several new species of Eubacterium, such as E. brachy, E. nodatum, E. timidum and E. yurii, have been found frequently from the subgingival area associated with various periodontal diseases (Holdeman et al., 1980; Hoshino et al., 1992b). Some species of oral Eubacterium have also been reported to be more numerous in subgingival sites with moderate and severe periodontitis than in supragingival sites or subgingival sites of healthy subjects (Moore et al., 1982 b, 1983, 1985; Han et al., 1991; Tanner et al., 1984; Wade et al., 1992). However, Eubacterium species still remain unfamiliar to many investigators because of their poor growth, tiny colony formation, fastidious nutritional requirements or strict anaerobic conditions for growth.

It is known that oral Eubacterium species are associated with enhanced aggregation of several pathogenic

*Author for correspondence. Tel. +8125223 6161, ext. 4165; fax +81252288771 . bacteria associated with periodontal diseases, bone resorption in the foetal rat and destruction of periodontal tissues (Mashimo et al., 1981; Vincent et al., 1984). It has been also reported that titres of immunoglobulin (Ig) $\mathrm{G}$ and IgA against Eubacterium species are significantly increased in patients with periodontitis (Gunsolley et al., 1990; Martin et al., 1986; Sandholm \& Tolo, 1986; Tew et al., 1985; Tolo \& Jorkjend, 1990; Tolo \& Schenk, 1985). These findings suggest that Eubacterium species may play an important role in the pathogenesis of periodontal disease.

Although serological reactions of antigenic polysaccharide isolated from strains of $E$. saburreum have been well documented in recent literature (Kondo et al., 1983; Nakazawa et al., 1987; Nakazawa \& Hoshino, 1992; Skaug \& Hofstad, 1983), no comprehensive study of the immunological relationships among the various species of the genus Eubacterium has been published. This study was designed to assess the serological relationship of oral Eubacterium species by using ultrasonic extracts from whole bacterial cells with SDSPAGE and Western immunoblot techniques.

\section{Methods}

Bacterial strains and culture conditions. Ten species and two subspecies of the genus Eubacterium including type species, several of which are often found in human oral cavities (Hoshino et al., 1992b), were selected for the present study. ATCC strains including Eubac- 
terium aerofaciens ATCC $25986^{\mathrm{T}}\left({ }^{\mathrm{T}}=\right.$ type strain), E. alactolyticum ATCC $23263^{\mathrm{T}}, E$. brachy ATCC $33089^{\mathrm{T}}$, E. lentum ATCC $25559^{\mathrm{T}}, E$. limosum ATCC $8486^{\mathrm{T}}, E$. nodatum ATCC $33099^{\mathrm{T}}$, E. rectale ATCC $33656^{\mathrm{T}}$, E. saburreum ATCC 33318 , E. timidum ATCC 33092, E. yurii subsp. yurii ATCC $43714^{\mathrm{T}}$ and $E$. yurii subsp. margaretiae ATCC $43715^{\mathrm{T}}$ were used as representatives of these species in this study. All bacterial strains were cultured in brain heart infusion broth supplemented with bovine serum, haemin and vitamin $\mathrm{K}_{1}$ (Holdeman et al., 1977). Cultures were incubated at $37^{\circ} \mathrm{C}$ for $3 \mathrm{~d}$ in an anaerobic chamber (Hirasawa Works, Tokyo, Japan) containing an atmosphere of $80 \% \mathrm{~N}_{2}, 10 \% \mathrm{H}_{2}$ and $10 \% \mathrm{CO}_{2}$. The bacterial cells were harvested by centrifugation at $10000 \mathrm{~g}$ for $20 \mathrm{~min}$ at $4{ }^{\circ} \mathrm{C}$ and washed with 10 mM-sodium phosphate-buffered saline, $\mathrm{pH} 7.2$ (PBS).

Production of polyclonal antisera. Whole bacterial cells to be used as immunogens were suspended at a concentration of $10 \mathrm{mg}$ (wet wt) $\mathrm{ml}^{-1}$ in sterile saline, and the suspensions $(0.1-1.0 \mathrm{ml})$ were intravenously injected into 10 -week-old female rabbits via the marginal ear vein twice a week for 3 or 4 weeks. The antisera were stored in small portions at $-80^{\circ} \mathrm{C}$ until used.

Preparation of antigens. Bacterial ultrasonic extracts were utilized as antigens for serological assays in this study. Whole bacterial cells (100 mg wet wt) were resuspended in $15 \mathrm{ml}$ of PBS and ultrasonicated with cooling until more than $95 \%$ of the cells had been disrupted, as determined by phase contrast microscopy. The extracts were centrifuged at $12000 \mathrm{~g}$ for $30 \mathrm{~min}$ at $4{ }^{\circ} \mathrm{C}$, and the supernatants were dialysed against distilled water, and lyophilized as antigens.

SDS-PAGE and Western immunoblot analysis. SDS-PAGE was carried out by the method of Laemmli (1970) in $7.5 \%(w / v)$ polyacrylamide gels $(1 \mathrm{~mm}$ thick), using a Micro Slab Gel Electrophoresis System KS-8010 (Marysol). Antigens $(50 \mu \mathrm{g})$ were solubilized in $0.125 \mathrm{M}$-Tris $/ \mathrm{HCl}$ buffer, $\mathrm{pH} 6.8$, containing $4 \%$ (w/v) SDS, $20 \%$ (v/v) glycerol and $5 \%(\mathrm{v} / \mathrm{v}) 2$-mercaptoethanol for $10 \mathrm{~min}$ at $100{ }^{\circ} \mathrm{C}$. Electrophoresis was conducted at constant $20 \mathrm{~mA}$ at room temperature. After electrophoresis, gels were stained with Coomassie brilliant blue R-250 or periodic acid-Schiff (PAS) base reagent, or used for Western transfer. The electrophoretic transfer of the antigens from the gel to nitrocellulose membrane (pore size, $0.45 \mu \mathrm{m}$; Bio-Rad) was performed by using the transfer buffer system described by Burnette (1981) in conjunction with the Trans Blot System (Marysol) at a constant current of $350 \mathrm{~mA}$ for $3 \mathrm{~h}$ with cooling. After Western transfer, the nitrocellulose membrane with the antigens was soaked for $1 \mathrm{~h}$ in $20 \mathrm{~mm}$ Tris/HCl-buffered saline (TBS; $\mathrm{pH} 7.5$ ), containing $1 \%(\mathrm{w} / \mathrm{v})$ bovine serum albumin (BSA), and then incubated with diluted rabbit antiserum $(1: 1000)$ as the first antibody for $2 \mathrm{~h}$ with mild agitation at room temperature. After washing with TBS containing $0.05 \%$ Tween 20, the nitrocellulose membrane was soaked in TBS containing $1 \%$ BSA and incubated with goat anti-rabbit IgG conjugated with peroxidase (1:1000 dilution: Cooper Biomedical) as the second antibody for $2 \mathrm{~h}$. Following washing, the membrane was placed in a mixture of 4-chloro-1-naphthol $(40 \mathrm{mg})$ dissolved in $5 \mathrm{ml}$ ethanol and $95 \mathrm{ml}$ TBS containing $0.015 \%$ hydrogen peroxide, for $10 \mathrm{~min}$, rinsed in distilled water and dried for storage.

Chemical analysis. Carbohydrate was quantified by the phenolsulphuric acid reaction using glucose as a standard (Hodge $\&$ Hofreiter, 1962). Protein was measured by the procedure of Lowry with BSA as standard.

Double-immunodiffusion assay. Immunodiffusion tests were carried out in $1.2 \%(\mathrm{w} / \mathrm{v})$ agar gel in PBS containing $0.02 \%$ sodium azide. Twenty microlitres of antigens $\left(5 \mathrm{mg} \mathrm{m}^{-1}\right.$ in PBS) and undiluted antisera were applied to each well.

Mild periodate oxidation. Periodate oxidation can distinguish between antibodies directed against carbohydrate and against peptide antigenic determinants, the latter being unaffected by the oxidation. In the present study, antigens on the nitrocellulose membrane were subjected to mild periodate oxidation by the method of Faye \& Chrispeels (1985). Briefly, after Western transfers, the nitrocellulose membrane with antigens was incubated for $2 \mathrm{~h}$ at room temperature in the dark with $0 \cdot 1 \mathrm{M}$-sodium acetate buffer, $\mathrm{pH} 4 \cdot 5$, containing $10 \mathrm{~mm}$ sodium metaperiodate for mild oxidation. At the end of the oxidation, each blot was soaked for $30 \mathrm{~min}$ with $50 \mathrm{mM}$-sodium borohydride in PBS. After these treatments, the membrane was rinsed with TBS and treated with the same procedures for Western immunoblot analysis as described above.

\section{Results}

The antigens (ultrasonic extracts) from each of the Eubacterium species contained $72 \cdot 8-80 \cdot 3 \%$ protein and widely different concentrations of carbohydrate, ranging from $0 \cdot 9-19 \cdot 4 \%$. The antigens from $E$. aerofaciens, $E$. alactolyticum, $E$. brachy, E. lentum, $E$. nodatum and $E$. saburreum were examined with the corresponding rabbit antisera in double-immunodiffusion assays. This preliminary study demonstrated that each antigen produced immunoprecipitin bands only with the homologous antiserum indicating that each Eubacterium species might induce species-specific antibodies, and that the specific immunological determinant might be contained in the ultrasonic extracts (Fig. 1). The relationships of serological reactions within the ten Eubacterium species and two subspecies were studied further using Western immunoblot assay following SDS-PAGE.

The SDS-PAGE assay of the 11 ultrasonic extract antigen preparations showed that all of them had a large

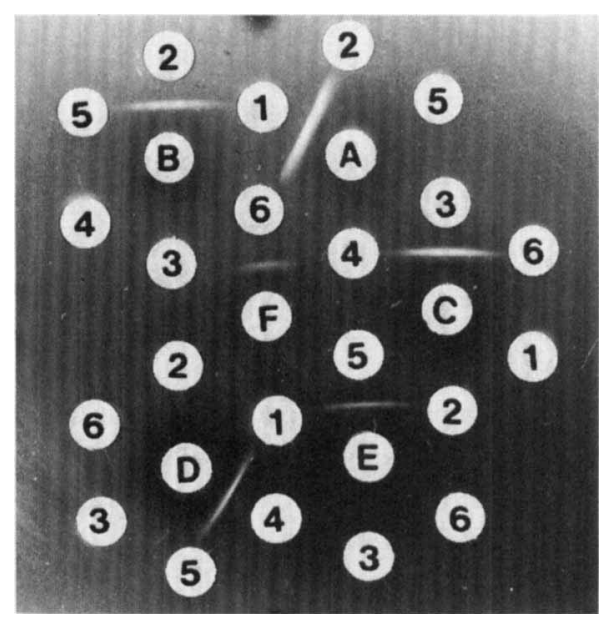

Fig. 1. Double-immunodiffusion reactions of antigens from six species of Eubacterium. Rabbit antisera, anti-E. aerofaciens ATCC $25986^{\mathrm{T}}$ (A), anti-E. alactolyticum ATCC $23263^{\mathrm{T}}(\mathrm{B})$, anti-E. brachy ATCC $33089^{\mathrm{T}}$ (C), anti-E. lentum ATCC $25559^{\mathrm{T}}$ (D), anti-E. nodatum ATCC $33099^{\mathrm{T}}$ (E), and anti-E. saburreum ATCC 33318 (F) sera, were undiluted. Antigens of $E$. aerofaciens ATCC $25986^{\mathrm{T}}$ (1), E. alactolyticum ATCC $23263^{\mathrm{T}}(2)$, E. brachy ATCC $33089^{\mathrm{T}}(3)$, E. lentum ATCC $25559^{\mathrm{T}}(4)$, E. nodatum ATCC $33099^{\mathrm{T}}$ (5), and E. saburreum ATCC 33318 (6) were prepared as described in the text. 


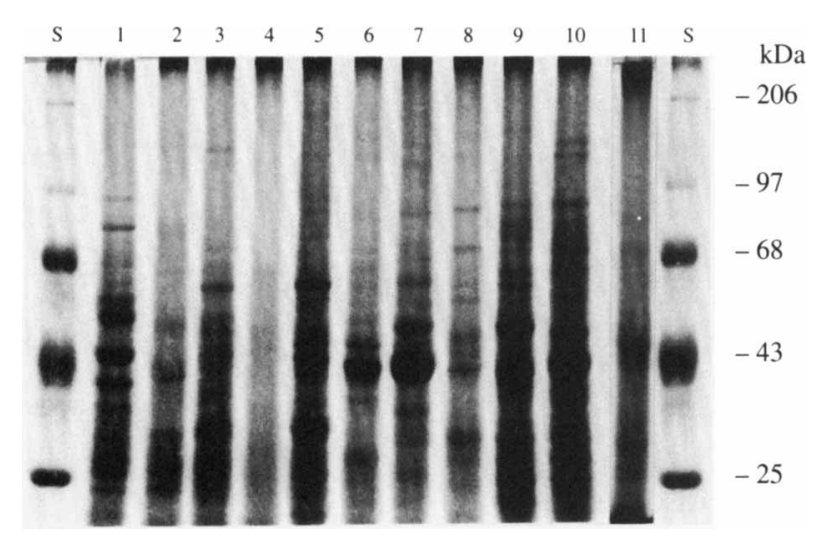

Fig. 2. SDS-PAGE profiles of the antigens from Eubacterium species. Lanes: $1, E$. aerofaciens ATCC $25986^{\mathrm{T}} ; 2, E$. alactolyticum ATCC $23263^{\mathrm{T}} ; 3$, E. limosum ATCC $8486^{\mathrm{T}} ; 4$, E. rectale ATCC $33656^{\mathrm{T}} ; 5$, E. saburreum ATCC 33318; 6, E. brachy ATCC $33089^{\mathrm{T}}$; 7, E. lentum ATCC $25559^{\mathrm{T}} ; 8, E$. nodatum ATCC $33099^{\mathrm{T}} ; 9$, E. yurii subsp. yurii ATCC $43714^{\mathrm{T}} ; 10$, E. yurii subsp. margaretiae ATCC $43715^{\mathrm{T}} ; 11, E$. timidum ATCC 33092; S, protein standards.

number of bands in the region between about $20 \mathrm{kDa}$ and $110 \mathrm{kDa}$ (Fig. 2). Except for E. yurii subsp. yurii and $E$. yurii subsp. margaretiae, the protein profile patterns were quite distinct from each other, and no major bands were shared among these antigens from the 10 species of Eubacterium (Fig. 2). No bands were shown from any antigen preparations when the gels were stained with PAS base reagent (data not shown).

The Western immunoblot assays with anti-rabbit IgG as conjugate revealed that only their homologous antigens reacted strongly with anti-E. aerofaciens (Fig. $3 a$ ), anti-E. alactolyticum (Fig. $3 b$ ), anti-E. saburreum (Fig. $3 e$ ), anti-E. nodatum (Fig. $3 h$ ), anti-E. yurii subsp. margaretiae (Fig. $3 j$ ) and anti-E. timidum (Fig. $3 k$ ) rabbit sera. However, antisera against $E$. brachy (Fig. $3 f$ ), $E$. lentum (Fig. 3g), E. limosum (Fig. 3c), E. rectale (Fig. $3 d$ ) and E. yurii subsp. yurii (Fig. $3 i$ ) also showed weak or positive cross-reactions with antigens from several different species. Antigens from $E$. aerofaciens, $E$. alactolyticum, $E$. rectale, $E$. brachy, $E$. lentum and $E$. timidum reacted weakly with anti-E. limosum rabbit serum. The antigen of $E$. yurii subsp. yurii reacted weakly with anti-E. rectale serum, and that of $E$. timidum reacted weakly with anti-E. brachy serum. Antigens from $E$. rectale and $E$. limosum showed weak cross-reaction with anti-E. lentum serum. Anti-E. yurii subsp. yurii serum reacted with the antigen of $E$. yurii subsp. margaretiae, but anti-E. yurii subsp. margaretiae serum did not react with the antigen of $E$. yurii subsp. yurii. The serological reactions within these Eubacterium species shown by Western immunoblot assays are summarized in Table 1.

Mild periodate oxidation of the antigens on nitrocellulose membranes was used to determine whether carbohydrate moieties of the antigens acted as the immunodeterminants that reacted with the antiserum. The periodate oxidation at acidic $\mathrm{pH}$ specifically cleaves carbohydrate vicinal hydroxyl groups without altering the structure of polypeptide chains. In this study, mild oxidation did not change any serological reactions of the antigens from these Eubacterium species in the Western immunoblot assay indicating that it is the peptide moieties of the antigens that react with the antisera (data not shown).

\section{Discussion}

In the present study, the ultrasonic extracts of whole bacterial cells were used for SDS-PAGE and Western immunoblot assay as antigens because they may include more components that have immunological activity than materials extracted by specific methods such as extraction by organic solvents, surfactants or enzymes. There were no detectable bands in the SDS-PAGE gel stained with PAS base reagents although sensitivity of PAS staining is lower than that of Coomassie brilliant blue. It indicated that the extracts were mainly composed of peptides, which was in agreement with the results of chemical analysis.

The SDS-PAGE analysis with Coomassie brilliant blue revealed that the 10 species of Eubacterium tested in this study displayed distinct differences of protein profile patterns apart from the antigens from $E$. yurii subsp. yurii and $E$. yurii subsp. margaretiae which showed a more similar profile pattern (Fig. 2, lanes 9 and 10). It was reported by Margaret \& Krywolap $(1986,1988)$ that SDS-PAGE of cell lysates of the three subspecies, $E$. yurii subsp. yurii, E. yurii subsp. margaretiae and $E$. yurii subsp. schtitka, isolated from human dental plaque, showed some common protein bands but their profile patterns were distinct from each other. In this study, major peptide bands shared by all species were not detected in the SDS-PAGE gel although it was possible that minor bands might be shared. These results of SDSPAGE analysis demonstrated that Eubacterium species showed great heterogeneity in protein components including structural proteins of whole bacterial cells.

Major bands on nitrocellulose membrane, which were visualized with homologous antisera in Western immunoblot assay, did not react with antisera raised against different species. There were no common cross-reactive antigenic bands shared over the whole range of species, although a few cross-reactions were observed. The serological reactions among 10 species of Eubacterium examined in the present study thus demonstrated considerable species specificity.

Margaret \& Krywolap (1988) reported that antisera to E. yurii subsp. yurii and E. yurii subsp. margaretiae 
(a)

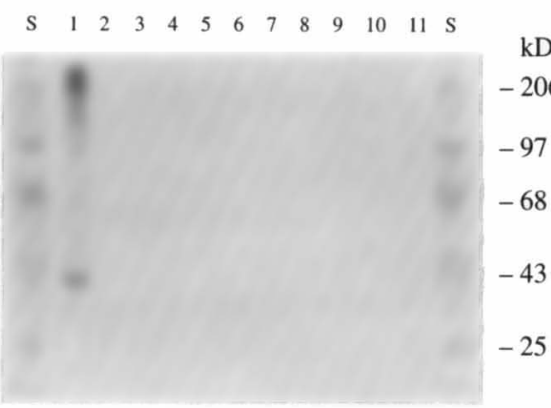

(b)

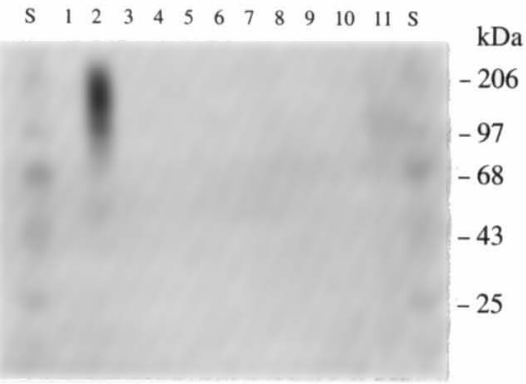

(c)

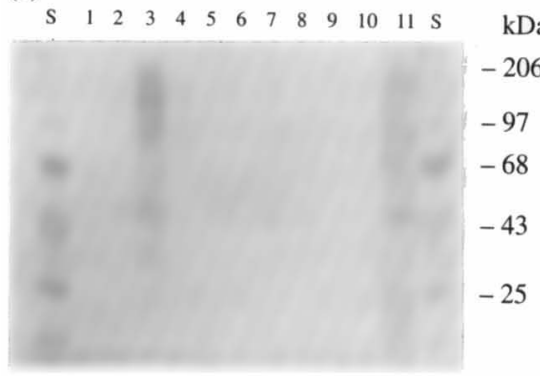

(d)

$\begin{array}{lllllllllllll}\mathrm{S} & 1 & 2 & 3 & 4 & 5 & 6 & 7 & 8 & 9 & 10 & 11 & \mathrm{~S}\end{array}$

$-97$

$-43$

$-25$ (e)

$\begin{array}{lllllllllllll}\mathrm{S} & 1 & 2 & 3 & 4 & 5 & 6 & 7 & 8 & 9 & 10 & 11 & \mathrm{~S}\end{array}$

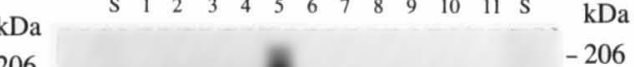

$-68$

(f)

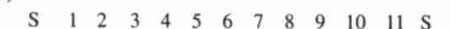

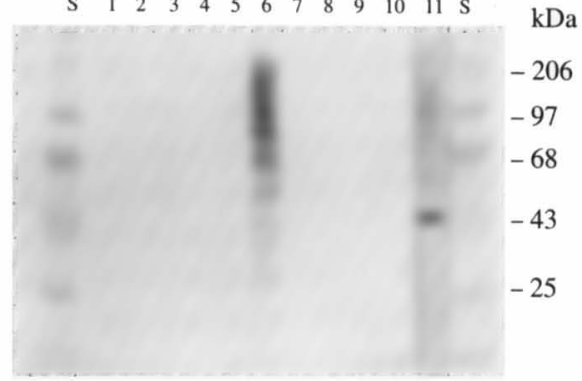

(g)

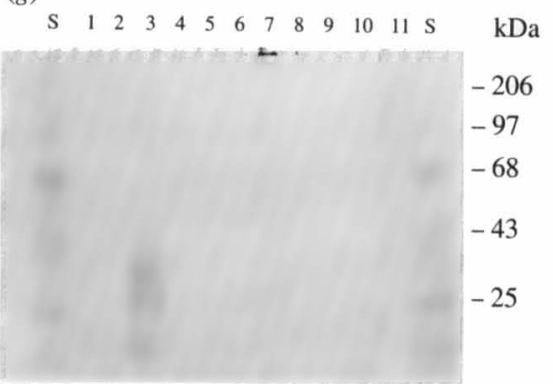

(h) (i)

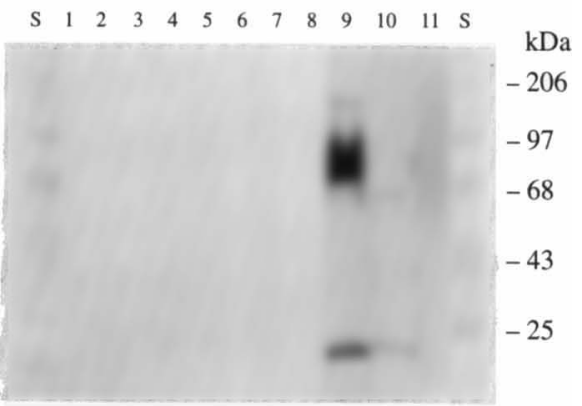

(j)

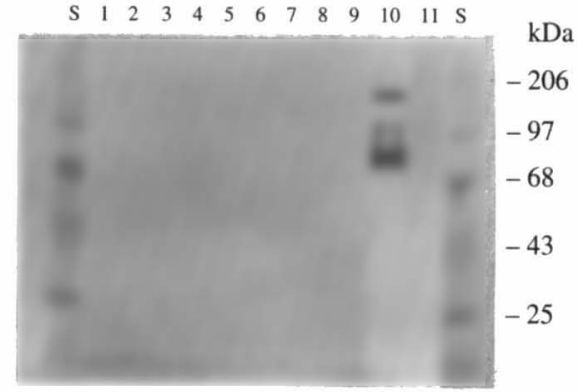

(k)

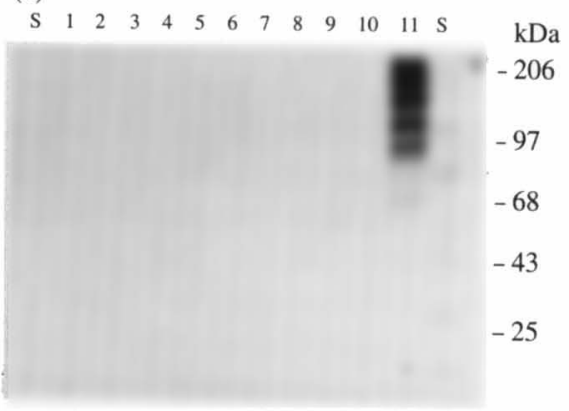

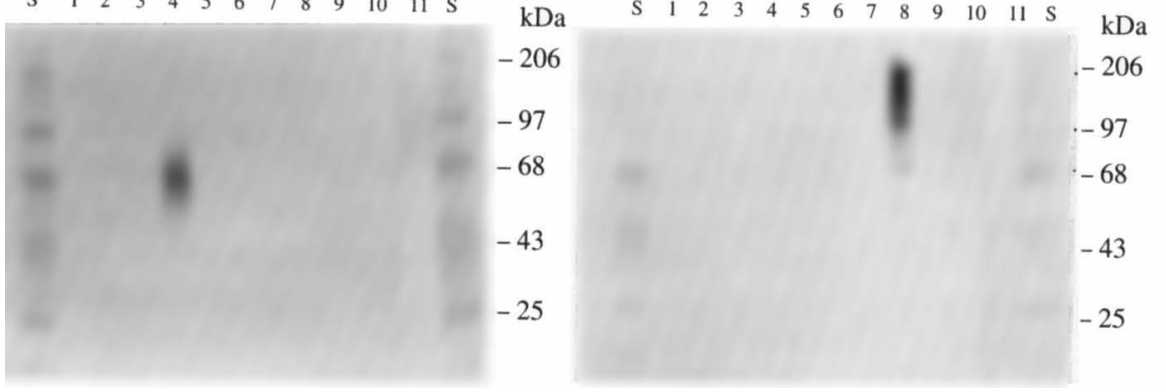

Fig. 3. Western immuno-blotting reactions of the antigens from Eubacterium species, which were recognized by their rabbit antisera. Lanes correspond to those in Fig. 2. Antisera: panels (a) anti-E. aerofaciens ATCC $25986^{\mathrm{T}} ;(b)$ anti-E. alactolyticum ATCC $23263^{\mathrm{T}}$; (c) anti-E. limosum ATCC $8486^{\mathrm{T}} ;(d)$ anti-E. rectale ATCC $33656^{\mathrm{T}} ;(e)$ anti-E. saburreum ATCC $33318^{\mathrm{T}} ;(f)$ anti-E. brachy ATCC $33089^{\mathrm{T}} ;(g)$ anti-E. lentum ATCC $25559^{\mathrm{T}} ;(h)$ anti-E. nodatum ATCC $33099^{\mathrm{T}}$; $(i)$ anti-E. yurii subsp. yurii ATCC $43714^{\mathrm{T}} ;(j)$ anti- $E$. yurii subsp. margaretiae ATCC $43715^{\mathrm{T}}$; and $(k)$ anti-E. timidum ATCC 33092.

reacted only with their homologous subspecies in serological tests using immunodiffusion in agar. In the present study, anti-E. yurii subsp. margaretiae serum did not react with the antigen of E. yurii subsp. yurii, but anti-E. yurii subsp. yurii serum reacted with the antigen of $E$. yurii subsp. margaretiae. This discrepancy between 
Table 1. Western immuno-blotting reactions of the antigens from Eubacterium species

Antigens $(a-k)$ correspond to the bacteria that are indicated in the column for antisera $(A-K)$.

\begin{tabular}{|c|c|c|c|c|c|c|c|c|c|c|c|c|}
\hline & \multirow[b]{2}{*}{ Antiserum } & \multicolumn{11}{|c|}{ Antigen* } \\
\hline & & a & b & c & d & e & f & g & $\mathbf{h}$ & $\mathrm{i}$ & $\mathrm{j}$ & $\mathbf{k}$ \\
\hline A & E. aerofaciens ATCC $25986^{\mathrm{T}}$ & + & - & - & - & - & - & - & - & - & - & - \\
\hline B & E. alactolyticum ATCC $23263^{\mathrm{T}}$ & - & + & - & - & - & - & - & - & - & - & - \\
\hline $\mathrm{C}$ & E. limosum ATCC $8486^{\mathrm{T}}$ & w & $\mathrm{w}$ & + & w & - & $\mathbf{w}$ & $\mathbf{w}$ & - & - & - & + \\
\hline D & E. rectale ATCC $33656^{\mathrm{T}}$ & - & - & - & + & - & - & - & - & w & - & - \\
\hline $\mathbf{E}$ & E. saburreum ATCC 33318 & - & - & - & - & + & - & - & - & - & - & - \\
\hline $\mathbf{F}$ & E. brachy ATCC $33089^{\mathrm{T}}$ & - & - & _ & _ & - & + & - & - & _ & _ & + \\
\hline G & E. lentum ATCC $25559^{\mathrm{T}}$ & - & - & + & w & - & - & + & - & - & - & - \\
\hline $\mathbf{H}$ & E. nodatum ATCC $33099^{\mathrm{T}}$ & - & - & - & - & - & - & - & + & - & - & - \\
\hline I & E. yurii subsp. yurii ATCC $43714^{\mathrm{T}}$ & - & - & - & - & - & - & - & - & + & $\mathbf{w}$ & - \\
\hline $\mathbf{J}$ & E. yurii subsp. margaretiae ATCC $43715^{\mathrm{T}}$ & - & - & - & - & - & - & - & - & - & + & - \\
\hline $\mathbf{K}$ & E. timidum ATCC 33092 & - & - & - & - & - & - & - & - & _ & - & + \\
\hline
\end{tabular}

$*+$, Positive reaction; - , negative reaction; $w$, weakly positive reaction.

two studies may be due to the method of antigen preparation or the sensitivity of the assay.

When goat anti-rabbit IgM instead of IgG as conjugate for Western immunoblot assay was applied, there were no visible bands in any ultrasonic extract antigen preparations from these Eubacterium species. Although we have no clear explanation for this result, it may be due to the period of stimulation for immunization. Also, it may be related to the fact that the antigens consist mainly of proteins, as shown by SDS-PAGE stained with PAS, chemical analysis and mild periodate oxidation which indicates that the immunodeterminants of the antigens are peptide moieties.

Recently numerous strains belonging to genus Eubacterium have been isolated from periodontal regions, including periodontal pocket, supragingival plaque and various sites affected by periodontitis (Theilade et al., 1982). These oral Eubacterium species have been suggested to be potential etiologic periodonto-pathogens in many bacteriological studies (Margaret \& Krywolap, 1988; Martin et al., 1986; Sandholm, 1985, 1987; Sandholm \& Tolo, 1986; Vincent et al., 1984). Immunological studies (Gunsolley et al., 1990; Sandholm, 1987; Tew et al., 1985; Vincent $e$ t al., 1985) have also indicated that certain species of Eubacterium may play important immunological roles in the progression of periodontal disease.

Uematsu \& Hoshino (1992) and Wade et al. (1991) reported that there were many unnamed Eubacterium species in the periodontal regions. At the present time, classification of the genus Eubacterium is based on elimination of other anaerobic genera (Moore \& Moore, 1986). The asaccharolytic members of the genus Eubacterium have proved difficult to identify because these micro-organisms show little reactivity in most biochemi- cal tests (Hill et al., 1987; Holdeman et al., 1980; Uematsu \& Hoshino, 1992). Therefore, it has been suggested that the genus Eubacterium may include some species that are phylogenetically distant from each other. Indeed, although more than 40 species have been recognized in Bergey's Manual of Systematic Bacteriology, these species may exhibit a variety of cellular morphologies, and are biochemically and physiologically extremely heterogeneous (Moore \& Moore, 1986). The recent studies of antigens from strains of $E$. saburreum and $E$. brachy may indicate great heterogeneity of chemical and antigenic properties among these microorganisms (Kondo et al., 1983; Nakazawa, 1985; Nakazawa \& Hoshino, 1992; Skaug \& Hofstad, 1983; Vincent et al., 1984).

The present study has demonstrated that the oral Eubacterium species tested could be clearly distinguished serologically by species-specific bands of antigens, which indicates immunological heterogeneity within Eubacterium species, and they also showed great heterogeneity in structural peptide components of whole bacterial cells. These results may be useful in identification of Eubacterium species, and may suggest the necessity for reclassification of the genus Eubacterium.

This study was supported in part by grant-in-aid for scientific research from the Ministry of Education, Science and Culture of Japan (Nos 01771462 and 04807130).

\section{References}

ANdo, N. \& Hoshino, E. (1990). Predominant obligate anaerobes invading the deep layers of root canal dentine. International Endodontic Journal 23, 20-27.

BURNETTE, W. N. (1981). Western blotting electrophoretic transfer of proteins from sodium dodecyl sulfate-polyacrylamide gels to unmodi- 
fied nitrocellulose and radiographic detection with antibody and radioiodinated protein A. Analytical Biochemistry 112, 195.

EDWARDSSON, S. (1974). Bacteriological studies on deep areas of carious dentine. Odontolgisk Revy 25 (suppl. 32), 1-143.

FAYE, L. M. J. \& ChrispeELS, M. L. (1985). Characterization of $N$ linked oligosaccharides by affinoblotting with concanavalin $\mathrm{A}$ peroxidase and treatment of the blots with glycosidases. Analytical Biochemistry 149, 218-224.

Gunsolley, J. C., Tew, J. G., Gooss, C., Marshall, D. R., BuRMEISTER, J. A. \& SCHENKeIN, H. A. (1990). Serum antibodies to periodontal bacteria. Journal of Periodontology 61, 412-419.

Han, N., XiaO, X., ZhaNG, L., RI, X., Zhang, J., Tong, Y., YANG, M. \& XIAO, Z. (1991). Bacteriological study of juvenile periodontitis in China. Journal of Periodontal Research 26, 409-414.

Hill, G. B., Ayers, O. M. \& Kohan, A. P. (1987). Characteristics and sites of infection of Eubacterium nodatum, Eubacterium timidum, Eubacterium brachy, and other asaccharolytic eubacteria. Journal of Clinical Microbiology 25, 1540-1545.

Hodge, J. E. \& Hofreiter, B. T. (1962). Phenol-sulfuric acid colorimetric method. Methods of Carbohydrate Chemistry 1, 388-394.

Holdeman, L. V., Cato, E. P. \& MoORE, W. E. C. (1977). Media. In Anaerobe Laboratory Manual, 4th edn, pp. 141-147. Edited by L. V. Holdeman, E. P. Cato \& W. E. C. Moore. Blacksburg: Virginia Polytechnic Institute and State University.

Holdeman, L. V., Cato, E. P., Burmeister, J. A. \& Moore, W. E. C. (1980). Descriptions of Eubacterium timidum sp. nov., Eubacterium brachy sp. nov., and Eubacterium nodatum sp. nov isolated from human periodontitis. International Journal of Systematic Bacteriology 30, 163-169.

Hoshino, E. (1985). Predominant obligate anaerobes in human carious dentine. Journal of Dental Research 64, 1195-1198.

Hoshino, E., ANDo, N., SAto, M. \& Kota, K. (1992a). Bacterial invasion of non-exposed dental pulp. International Endodontic Journal 25, 2-5.

Hoshino, E., Sato, N., Nakazawa, F., Uematsu, H., Sato, M., Ikeda, T., Kurihara, N., Sato, T. \& Sato, M. M. (1992b). Oral Eubacterium. Niigata Dental Journal 22, 1-14.

Kondo, W., Nakazawa, F., Sato, M. \& Ito, T. (1983). Structural studies of the antigenic polysaccharide of Eubacterium saburreum, strain T27. Carbohydrate Research 117, 125-131.

LAEMMLI, U. K. (1970). Cleavage of structural proteins during the assembly of the head of bacteriophage T4. Nature, London 227, $680-685$.

MARGARET, B. S. \& KRYwOlaP, G. N. (1986). Eubacterium yurii subsp. yurii sp. nov. and Eubacterium yurii subsp. margaretiae subsp. nov.: test tube brush bacteria from subgingival dental plaque. International Journal of Systematic Bacteriology 36, 145-149.

MARGARET, B. S. \& KRYwOLAP, G. N. (1988). Eubacterium yurii subsp. schtitka subsp. nov.: test tube brush bacteria from subgingival dental plaque. International Journal of Systematic Bacteriology 38, 207-208.

Martin, S. A., FAlKLeR, W. A. JR, Vincent, J. W., MACKLeR, B. F. \& SUzUKI, J. B. (1986). A comparison of the reactivity of Eubacterium species with localized and serum immunoglobulins from rapidly progressive and adult periodontitis patients. Journal of Periodontology 59, 32-39.

Mashimo, P. A., Murayama, Y., Reynolds, H., Mouton, C., Ellison, S. A. \& GenCo, R. J. (1981). Eubacterium saburreum and Veillonella parvula. Journal of Periodontology 52, 374-379.

MOORE, W. E. C. \& MOORE, L. V. H. (1986). Genus Eubacterium. In Bergey's Manual of Systematic Bacteriology, pp. 1353-1372. Edited by P. H. A. Sneath, N. S. Mair, M. E. Sharpe \& J. G. Holt. Baltimore: Williams \& Wilkins.

Moore, W. E. C., Holdeman, L. V., Smibert, R. M., Hash, D. E., BURMeISTER, J. A. \& RANNEY, R. R. (1982a). Bacteriology of severe periodontitis in young adult humans. Infection and Immunity 38, $1137-1148$
MoOre, W. E. C., Ranney, R. R. \& Holdeman, L. V. (1982b). Subgingival microflora in periodontal disease: culture studies. In Host Parasite Interaction in Periodontal Disease, pp. 13-26. Edited by R. J. Genco \& S. E. Mergenhagen. Washington DC: American Society for Microbiology.

Moore, W. E. C., Holdeman, L. V., Cato, E. P., Smibert, R. M., BURMEISTER, J. A. \& RANNEY, R. R. (1983). Bacteriology of moderate (chronic) periodontitis in mature adult humans. Infection and Immunity 42, 510-515.

Moore, W. E. C., Holdeman, L. V., Cato, E. P., Smibert, R. M., Burmeister, J. A., Palcanis, K. G. \& RanNey, R. R. (1985). Comparative bacteriology of juvenile periodontitis. Infection and Immunity 48, 507-519.

NaKaZAWA, F. (1985). Structural studies of the antigenic polysaccharide of Eubacterium saburreum, strain T17. Carbohydrate Research 143, 185-190.

NAKAZAWA, F. \& Hoshino, E. (1992). Immunochemical and structural characterization of the antigenic polysaccharide from Eubacterium saburreum T18. Oral Microbiology and Immunology 7, 182-186.

Nakazawa, F., Ito, T., Sato, N., Sato, M. \& Hoshino, E. (1987). Chemical composition and immunological characterization of polysaccharide antigen from Eubacterium saburreum T18. Infection and Immunity 55, 871-876.

SANDHOLM, L. (1985). Bacteriology of juvenile periodontitis. A review. Proceedings of the Finnish Dental Society 81, 63-76.

SANDHOLM, L. (1987). Serum and salivary antibodies in various periodontal conditions. Proceedings of the Finnish Dental Society 83, 151-155.

SANDHOLM, L. \& Tolo, K. (1986). Serum antibody levels to 4 periodontal pathogens remain unaltered after mechanical therapy of juvenile periodontitis. Journal of Clinical Periodontology 13, 646-650.

SKAUG, N. \& HoFSTAD, T. (1983). Eubacterium saburreum L13 antigen containing a ketohexose as a main sugar constitutent. Infection and Immunity 39, 179-183.

TANNER, A. C. R., Socransky, S. S. \& Goodson, J. M. (1984). Microbiota of periodontal pockets losing crestal alveolar bone. Journal of Periodontal Research 19, 279-291.

Tew, J. G., Mareshall, D. R., Moore, W. E. C., Best, A. M., Palcanis, K. G. \& RANNEY, R. R. (1985). Serum antibody reactive with predominant organisms in the subgingival flora of young adults with generalized severe periodontitis. Infection and Immunity 48, 303-311.

Theilade, E., Fejerskov, O., Karring, T. \& Theilade, J. (1982). Predominant cultivable microflora of human dental fissure plaque. Infection and Immunity 36, 977-982.

ToLO, K. \& JORKJEND, L. (1990). Serum antibodies and loss of periodontal bone in patients with rheumatoid arthritis. Journal of Clinical Periodontology 17, 288-291.

ToLo, K. \& SCHENCK, K. (1985). Activity of serum immunoglobulins $G, A$ and $M$ to six anaerobic, oral bacteria in diagnosis of periodontitis. Journal of Periodontal Research 20, 113-121.

Uematsu, H. \& Hoshino, E. (1992). Predominant obligate anaerobes in human periodontal pockets. Journal of Periodontal Research 27, 15-19.

Vincent, J. K., FalkleR, W. A. JR \& Heath, J. R., III (1984). Eubacterium brachy: reactivity in in vitro bone resorptive bioassay. Journal of Periodontology 55, 93-97.

Vincent, J. K., Falkier, W. A. Jr, Dalessandro, N. F., Miller, R. A. \& HeATH, J. R., III (1985). Reaction of human sera with Eubacterium brachy: isolation and characterization of an extracellular antigen. Infection and Immunity 47, 592-597.

Wade, W. G., Gray, A. R., Absi, E. \& Barket, G. R. (1991). Predominant cultivable flora in pericoronitis. Oral Microbiology and Immunology 6, 310-312.

Wade, W. G., Moran, J., Morgan, J. R., Newcombe, R. \& Addy, M. (1992). The effects of antibacterial acrylic strips on the subgingival microflora in chronic periodontitis. Journal of Clinical Periodontology 19, 127-134. 